\title{
Biomarkers: a strategic tool in the assessment of environmental quality of coastal waters
}

\author{
Ana Picado - M. J. Bebianno $\cdot$ M. H. Costa \\ A. Ferreira - C. Vale
}

(C) Springer Science+Business Media B.V. 2007

Guest editors: M. J. Costa, H. Cabral \& J. L. Costa

Towards an integrated knowledge and management of estuarine systems

\section{A. Picado $(\square)$}

INETI, Estrada Paço Lumiar, 1649-038 Lisbon,

Portugal

e-mail: ana.picado@ineti.pt

\section{J. Bebianno}

CIMA, FCMA, University of Algarve, Campus de Gambelas, 8000 Faro, Portugal

M. H. Costa

IMAR, DCEA, New University of Lisbon, Quinta da Torre, 2829-516 Caparica, Portugal

\section{A. Ferreira $\cdot$ C. Vale}

INIAP-IPIMAR, Av. Brasilia, 1449-006 Lisbon, Portugal at the individual, population and community levels. Monitoring programs should make use of this tool to link contaminants and ecological responses fulfilling strategies like those launched by OSPAR (Commissions of Oslo and Paris) Convention on the protection of the marine environment of the North-East Atlantic and the International Council for the Exploration of the Sea (ICES). An overview of the work done in the past few years using biomarkers as in situ tools for pollution assessment in Portuguese coastal waters is presented as a contribution to the set up of a biomonitoring program for the Portuguese coastal zone. Considering the data set available the biomonitoring proposal should include the analysis of biomarkers and effects at individual levels. The aim of the program will include a spatial and temporal characterization of the biomarkers acetyl-cholinesterase, metallothioneins, DNA damage, adenylate energy charge and scope-for-growth levels. The investigation of the spatial variation of biomarkers is crucial to define sites for long term monitoring, which will be integrated with a chemical monitoring program. This framework will be a major contribution to the implementation of a national database for the use of biomarkers along the Portuguese coast.

Keywords Biomarkers of exposure .

Biomarkers of defence - Coastal waters .

\begin{tabular}{|c|c|c|c|c|}
\hline & Journal : HYDR & Dispatch : & 23-2-2007 & Pages: 9 \\
\hline & 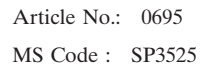 & $\begin{array}{l}\square \mathrm{LE} \\
\boldsymbol{\mathrm { CP }}\end{array}$ & & $\begin{array}{l}\square \text { TYPESET } \\
\varnothing \text { DISK }\end{array}$ \\
\hline
\end{tabular}


An assessment of the environmental quality of coastal waters in terms of chemical analysis on specific compounds fails in its objectives knowing that ecosystems are under the pressure of complex mixtures of contaminants not always simple to analyse. With the general spread of organic contaminants (such as herbicides, insecticides and antifouling agents) whose analytical measurements were difficult in water and likely to cause adverse effects in the marine environment attention turned to effects on biota (Lam \& Gray, 2003).

Marine organisms have the ability to accumulate contaminants from the environment where they live at much higher concentrations and, at the same time, showing much less spatial and temporal variability. Therefore, Mussel Watch programs have been used worldwide to assess pollution levels of coastal zones (Goldberg et al., 1978). However, levels of contaminants did not provide accurate information about the effects on the organisms. Therefore biological indicators have been used to provide accurate information about the health of marine ecosystems. An indicator may reflect biological, chemical or physical attributes of ecological condition. The primary uses of an indicator are to characterize current status and to track or predict significant changes that relay a complex message, potentially from numerous sources, in a simplified and useful manner. An ecological indicator is defined here as a measure, an index of measures, or a model that characterizes an ecosystem or one of its critical components. With a foundation of diagnostic research, an ecological indicator may also be used to identify major ecosystem stress. Other indicators called biomarkers are defined as quantitative measures of changes in the biological system that respond to either (or both) exposure to, and/or doses of substances that lead to biological effects and are potential tools for detecting either exposure to, or effects of, contaminants and give responses at different levels of biological organization: biochemical, physiological, organism and population (Lam \& Gray, 2003).

The assessment of biological effects reveals itself to be of great value in terms of management aiming to assess the quality of coastal waters. Over the years, many biomarkers have been developed that are efficient at providing an early warning of deleterious effects on biological systems and by the mid 1980s a wide range of biomarkers were developed and applied in monitoring programs. The monitoring of biological effects has recently become an integral component of environmental monitoring programs as a supplement to the commonly used contaminant monitoring (Lam \& Gray, 2003).

Goldberg \& Bertine (2000) underlined that the analysis of the detoxifying enzymes, cytochrome P-450, metallothioneins and estrogenic substances can provide useful information on the potential effects of several contaminants in the aquatic environment.

Therefore, future monitoring programs should make use of this tool to link contaminants and ecological responses fulfilling the strategies launched by the OSPAR convention (2004) and the International Council for the Exploration of the Sea (ICES). The OSPAR Convention that aims to protect the marine environment of the Northeast Atlantic requires taking all possible action to prevent and eliminate pollution. Under the Joint Assessment and Monitoring Programme and concerning the quality of the marine environment, monitoring for contaminants in water, sediment and biota are required. Also the ICES Strategy, stating "human activities on land and sea have an impact on marine ecosystems," aims to understand the physical and biological functioning of marine ecosystems as well as to evaluate the ecosystem effects of human activities. ICES also established a working group to study the application of biomarkers (ICES, 1997, 2001). The adoption of such a strategy will contribute to the challenge launched by the EU Water Framework Directive (WFD) concerning the objective of assessing the ecological effects of pollution.

Lagadic et al. (1997) underlined the importance of measuring several biomarkers at the same time in the same organisms, which allows a pertinent approach to evaluate the effects of pollutants on individuals. This multiparametric approach using different and/or complimentary biomarkers will enable an assessment of the

\begin{tabular}{|l|lll|}
\hline & Journal : HYDR & Dispatch : 23-2-2007 & Pages : 9 \\
Article No.: 0695 & $\square$ LE & $\square$ TYPESET \\
MS Code : $\quad$ SP3525 & $\boldsymbol{C P}_{\mathrm{CP}}$ & $\square$ DISK \\
\hline
\end{tabular}


effects of the different contaminants present in the aquatic environment. Although there is the need to develop research and validate results in the field and to improve the knowledge of the real physiological meaning of some of these indices, different biomarkers are being used in different countries as part of different marine monitoring programs. In 1995 OSPARCOM/ ICES agreed on a joint biological monitoring program for the North Sea (JAMP, 1998a, b). This is an example of an international program that has integrated the use of several biomarkers into a routine monitoring of coastal waters. At the national level, several countries have launched similar programs. The UK National Marine Monitoring Programme (NMMP UK, 2004) includes levels of contaminants in biota, water and sediments but also biological effect monitoring. In this monitoring program, biomarkers and/or bioassays are included, besides the chemical analysis of metals or organic compounds, such as PCBs and PAHs, namely.

In the Basque Country (Northern Spain) water quality and contaminants in molluscs have been monitored, since 1990, in five areas licensed previously for shellfish production (Franco et al., 2002). Those results were used to define the main patterns and temporal trends of pollutants in molluscs. Furthermore, since 1995, a monitoring program was established (Borja et al., 2004).

The aim of this paper is to outline a biological effect based monitoring program. These tools can be used for screening and for diagnosis, in trend analysis or for predictive purposes, including risk assessment (Den Besten, 1998).

\section{Biomarkers in the Portuguese coastal zone}

In the past few years several biomarkers have been used as in situ tools for the evaluation of pollution effects in different biological species sampled in different sites along the Portuguese coast or in sediment bioassays, by assessing multiple biological effects at several levels of biological organization. The results outlined here were not integrated under any kind of a national monitoring program. Examples of biomarker application are described below.
AEC is the energy balance for an organism at a given instant and is calculated by the equation (Atkinson \& Walton, 1967):

$$
\begin{aligned}
\mathrm{AEC}= & {[(\mathrm{ATP})+1 / 2(\mathrm{ADP})] /[(\mathrm{ATP})} \\
& +(\mathrm{ADP})+(\mathrm{AMP})]
\end{aligned}
$$

AEC theoretical values are situated between 0 and 1 . This biochemical index reaches high values (0.9) under optimal conditions but drops rapidly in the presence of stressing agents. In vertebrates, AEC is strongly regulated and maintained within narrow limits. In contrast, in invertebrates, AEC displays a wide range of values according to the importance of the internal stress or to the variations in the external environment of the organisms (natural or anthropogenic). Global indices, specifically an index based on the measurement of the metabolic energy pool, do have their place in any approach of long-term effects of low level contaminants present in marine environment (Howells et al., 1990).

Different studies were carried out in different species sampled in different sites, namely: the oyster Crassostrea angulata (Lamarck, 1819) collected at two sites along the Portuguese coast, the polychaete Lanice conchilega (Pallas, 1766) sampled in three sites of the Sado estuary and the clam Ruditapes decussatus (Linaeus, 1758) in the Aveiro and Ria Formosa lagoons. The appearance of a signal linked to the intensity of the stressor can indicate the limits of an active response of an organism. The use of AEC in field studies allowed a classification of different sites according to environmental conditions (Picado, 1997; Thébault et al., 2000).

\section{Genotoxicity}

Given the very important role that the DNA molecule plays in life and reproduction of each organism, a number of studies have concentrated on biomarkers of DNA damage to detect genotoxic effects of complex chemical mixtures in natural environments (Husby \& McBee, 1999; Theodorakis et al., 2000; Neuparth, 2004; 
Neuparth et al., 2005). Additionally, the detection of structural/functional disturbances to DNA enables the assessment of organismal health and can assist in the prevention of the proliferation of DNA damage in the food chain, including humans (Handy et al., 2002).

Several methods have been used for assessing DNA strand breaks in eukaryotic cells, being the comet assay, or single-cell gel electrophoresis (SCGE), one of the most common over the last decade. Nevertheless, compared to other techniques used to assess DNA damage, detection of DNA strand breakage by agarose gel electrophoresis has the advantage of determining insult to DNA integrity both qualitatively (single strandbreaks versus double strand-breaks) and quantitatively (number of strand breaks) (Neuparth et al., 2005). In addition it can also be applied to DNA extracted from whole organisms, thus not requiring manipulation of small specimens to collect specific tissues (Costa et al., 2002). Other genotoxicity biomarkers, such as nuclear abnormalities or nuclear DNA content variation, have also been used in several ecotoxicological studies to evaluate a different category of genotoxicity response-chromosomal damage (Gravato \& Santos, 2003; Maria et al., 2003 as examples of nuclear abnormalities studies, or: Bickham, 1990; Husby \& McBee, 1999; Neuparth, 2004, for nuclear DNA content variation studies). The use of multiple genotoxic biomarkers (DNA and chromosomal damage biomarkers) in the same organism showed to be very helpful in establishing cause-effect relationships more rigorously.

In Portugal these genotoxicity biomarkers have been applied mainly to fishes and crustaceans in estuarine environments and effluents receiving water bodies (Gravato \& Santos, 2003; Maria et al., 2003; Neuparth, 2004; Neuparth et al., 2005; Costa et al., 2005).

\section{Histopatology}

Studies addressing impacts at histological and cellular levels of organization are particularly important to establish the cause and effect relationships between exposure to contaminants and adverse health of organisms. Besides histopatol- ogies, like neoplastic lesions or functional disruption, detection of heavy metals can be a useful biomarker of exposure, particularly to demonstrate its bioavailability in the environment.

These kinds of effects address different target organs and tissues and distinct environmental disturbances.

Some examples can be mentioned: structural changes in the midgut gland of crustaceans (digestive diverticules histology and changes in the ultra structure of the epithelial cells) (Correia et al., 2002a, b), structural damage in the liver, gonads and gills of fishes and in the digestive gland and gonads of bivalves (Del Valls et al., 2004).

\section{Imposex/Intersex}

Organotin compounds are one of the more toxic compounds that man deliberately introduced in the aquatic environment and they have adverse effects on several species of marine organisms, which are not target of antifouling paints.

Effects of organotin compounds in the aquatic environment include shell malformation in oysters, the imposition of male sex organs on female neogastropods (imposex) reduced scope for growth and a consequent population decline in a variety of molluscs. Therefore, molluscs are the most sensitive taxa to chronic, low level exposure to organotin compounds, particularly to tributyltin (TBT).

Imposex is a well known biomarker of effect of organotin compounds in neogastro Prosobranch gastropods exhibit all types of sexuality and sexes are separated and unchanged throughout the life history of the individual. The impact of organotin compounds in these species revealed that imposex is irreversible and occurred in populations who live near the proximity of boat centres, harbours and marinas and is correlated with the concentration of TBT compounds accumulated in gastropod tissues. The masculinisation effect of TBT (initiated at a TBT concentration of around $0.5 \mathrm{ng} \mathrm{l}^{-1} \mathrm{Sn}$, or less, in the water) on female gastropods is well documented (Gibbs \& Bryan, 1986). During the past three decades, females of an increasing number of gonochoristic gastropods

\begin{tabular}{|l|lll|}
\hline & Journal : HYDR & Dispatch : 23-2-2007 & Pages : 9 \\
Article No.: 0695 & $\square$ LE & $\square$ TYPESET \\
MS Code : $\quad$ SP3525 & $\boldsymbol{C P}_{\mathrm{CP}}$ & $\square$ DISK \\
\hline
\end{tabular}


have been found to exhibit imposex and abnormal penis-bearing females have been recorded in over 200 gastropod species (Bettin et al., 1996; SchulteOehlmann et al., 2000) in coastal waters worldwide.

In European coastal waters, imposex in Nucella lapillus (Linnaeus, 1758) has been extensively used as a biomarker of TBT pollution because the masculinisation process occurs in a predictable manner (Bryan et al., 1986; Gibbs \& Bryan, 1986). However in areas where this species is unavailable imposex in the nassariids such as Nassarius (=Hinia) reticulatus (Linnaeus, 1758) has been used instead although in these species imposex does not seem to interfere with the female breeding activity. Along the coast of Portugal imposex levels in both species $N$. lapillus and $N$. reticulatus revealed that imposex was a spread phenomenon in estuarine and coastal waters. Female sterilization even occurred in the main harbours of the Portuguese Coast (Langston et al., 1998; Barroso et al., 2002, Santos et al., 2000, 2002).

\section{Metallothioneins (MTs)}

MTs are a family of peculiar proteins whose characteristics enable to differentiate them from all the other proteins. MTs are low molecular weight $(6-7 \mathrm{kDa})$ heat stable cytosolic proteins of non-enzymatic nature, ubiquitous in the animal kingdom. These proteins have an unusual amino acid composition: $1 / 3$ is cysteines in fixed positions of the molecule and with no aromatic amino acids. They are able to bind class $\mathrm{B}$ metal ions ( $\mathrm{Ag}>\mathrm{Hg}>\mathrm{Cu}>\mathrm{Cd}>\mathrm{Zn}$, 6-7 or 12 atoms per molecule) in two metal thiolate clusters linked by two lysines and metal ions are bound to the sulphur atoms of the cysteines (Dabrio et al., 2002).

Although the function of these proteins remained controversial, they are probably important in detoxification of non-essential and excess of essential metal ions ( $\mathrm{Cu}$ and $\mathrm{Zn}$ ) as well as in homeostasis of these essential metals. They are also induced by stress hormones and glucocorticoids and protect the cells against oxidative stress and function as radical scavengers and in gene regulation (Nordberg, 1998; Chan et al., 2002).
The use of MTs as a biomarker of metal exposure was proposed and included in the monitoring programs established by ICES and OSPAR referred to above.

Along the Portuguese coast MT have been measured in several bioindicator species namely mussels Mytilus galloprovincialis Lamarck, 1819, limpets Patella aspera (Röding, 1798) and clam Ruditapes decussatus. MT levels in mussels and limpets from different sites along the Southern Coast of Portugal revealed that MT concentrations are directly related with the increase of metal levels particularly of $\mathrm{Cd}$ and $\mathrm{Cu}$ and that all the soft tissues and the gills, particularly of the mussels, could be appropriate to monitor changes of metal levels in the Portuguese coastal environment (Bebianno \& Machado, 1997; Bebianno et al., 2003). In areas were mussels were less common, MT levels of an important economic shellfish species, the clam $R$. decussatus revealed that MT levels in different tissues were directly related with changes in $\mathrm{Cd}$ levels in the $\mathrm{Ria}$ Formosa lagoon and in this species the gills seemed to be the most appropriate tissue to monitor for MT concentrations (Bebianno et al., 2003; Bebianno \& Serafim, 2003).

\section{Scope for growth}

Scope for growth (SFG), or the energy available for growth and reproduction, is a stress index integrating physiological responses due to environmental changes, either natural or derived from human activity. It measures the balance between energy acquisition (assimilation) and energy loss processes (respiration and excretion) and has been widely used in environmental monitoring assessment, as well as to measure bivalve responses to several stress factors (Widdows \& Donkin, 1992), especially in the mussel Mytilus edulis Linnaeus, 1758.

Scope for growth is calculated using the expression $\mathrm{SFG}=\mathrm{A}-(\mathrm{R}+\mathrm{U})$. All rates, assimilation rates (A), respiration rates $(\mathrm{R})$ and excretion rates $(\mathrm{U})$ are weight standardized to a body mass close to that of the animals measured and converted to Joules (Widdows \& Donkin, 1992).
400

\begin{tabular}{|l|lll|}
\hline & Journal : HYDR & Dispatch : 23-2-2007 & Pages : 9 \\
Article No.: 0695 & $\square$ LE & $\square$ TYPESET \\
MS Code : SP3525 & $\square$ CP & \multicolumn{1}{c}{ DISK } \\
\hline
\end{tabular}


In Portugal, as elsewhere, it has been applied mainly to bivalves (Sobral \& Widdows, 1997, 2000) but also to other invertebrates (Fernandes et al., 2002).

\section{Biomarkers and scales of classification}

Whether it is assumed that biomarkers are of great potential for environmental monitoring assessment it has also been stressed that caution should be given to their application. These tools can be used for screening, for diagnosis, in trend analysis or for predictive purposes (den Besten, 1998). It has been recognised that the evaluation of risk assessment should also take into account the effects on the biota (Cajaraville et al., 2000).

Narbonne et al. (1999) proposed a scale of classification based on selected biomarkers, including enzymes indicators of oxidative stress and cholinesterase activity, among early molecular events related to toxicological mechanisms of some contaminants in mussels. This global biomarker index (BI) is calculated as the sum of the individual biomarkers measured and is based on discriminatory factors calculation. High values of the Biomarker Index stand for sites exposed to industrial or domestic water release whereas lower BI values were found in the open sea or in sites without industrial or agricultural activities. Anyhow, there is the need to go further with this issue in order to establish reliable environmental indices for the quality assessment of the coastal environment and for management purposes.

\section{Proposal for monitoring program based on biomarkers}

Besides the chemical analysis of several contaminants in the biotic and abiotic compartments of coastal ecosystems, which vary geographically (Caetano \& Vale, 2003; Quental et al., 2003), biomarkers should be incorporated in national or regional monitoring programs, to assess the biological effects of contaminants present in the coastal environment. Each program should be defined according to local specificities, namely the existing data for hydrodynamics, chemical characterization and enough data for a set of biomarkers concerning ecological relevant species.

The aims of the Portuguese program proposal should include a spatial and temporal characterization of the following biomarkers: adenylate energy charge and scope-for-growth, acetyl-cholinesterase, metallothioneins and genetics biomarkers and also imposex in the hot spots of the Portuguese coastal zones already identified by the chemical analysis. In specific sites, the presence of histopatologies should be assessed, as complementary information. The Portuguese coast should be divided into three areas; Area 1- From Caminha to Figueira da Foz; Area 2- from Figueira da Foz to Sines; Area 3- from Sines to Vila Real de Santo António (Fig. 1).

Several sites among traffic separation schemes should also be included between Berlengas and Cabo da Roca. The strategy should be based on coastal ecosystems that have been identified as

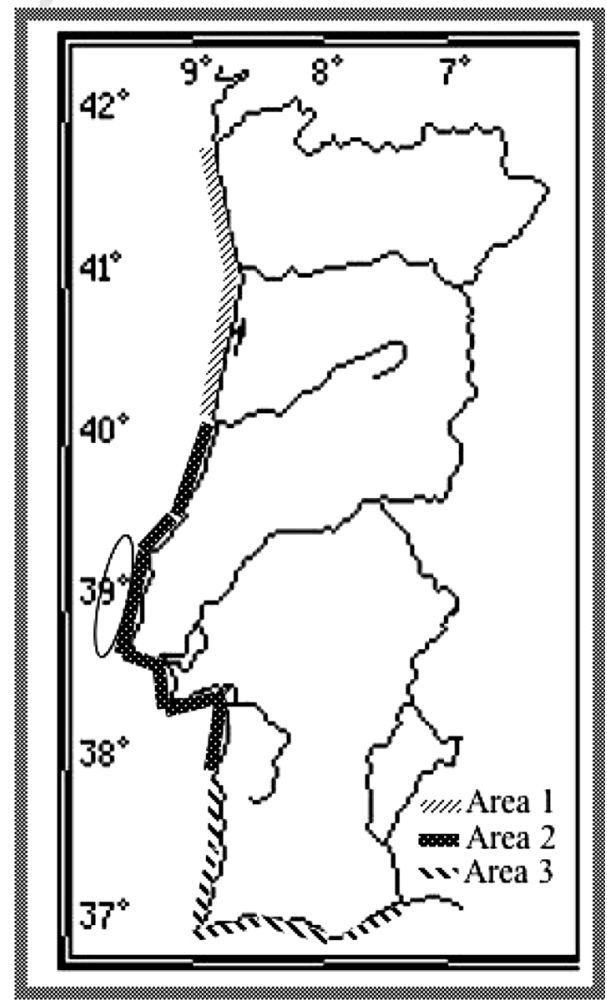

Fig. 1 Monitoring areas. Area1: from Caminha to Figueria da Foz; Area 2: from Figueira da Foz to Sines (encircled the area between Berlengas and Cabo da Rocha); Area 3: from Sines to Vila Real de Santo António

\begin{tabular}{|l|lll|}
\hline & Journal : HYDR & Dispatch : 23-2-2007 & Pages : 9 \\
Article No.: 0695 & $\square$ LE & $\square$ TYPESET \\
MS Code : SP3525 & $\nabla_{\text {CP }}$ & $\varnothing$ DISK \\
\hline
\end{tabular}


having high contamination levels, that are directly affected by pollution point sources and others not directly affected by these sources (control sites). Biomarker levels should be compared among sites. The first step should be to investigate the spatial variation of biomarkers in order to define sites for long term monitoring. This framework would be a major contribution to the implementation of a national database for the use of biomarkers along the Portuguese coast. Apart from biomarkers, contaminants should be analysed in water and sediments to try to establish a cause and effect relationship between contaminant levels and biological effects. Organisms to be analysed for the several biomarkers should include molluscs (Mytilus galloprovincialis, Ruditapes decussates, Nassarius reticulatus and Nucella lapillus); Polychaetes [Nereis diversicolor (Müller, 1776)]; Crustaceans [Carcinus maenas (Linnaeus, 1758) and Gammarus locusta Linneus, 1758] and Fishes [Platichthys flesus (Linneus, 1758) and Mugil cephalus Linneus, 1758]. Several methods should be used for each of the biomarkers: AchE, AEC, EROD, MT, Genotoxicity, Scope for Growth, imposex. For organotin compounds sampling should be every three to five years while for the others sampling will be yearly.

Based on the results a database and data management should be implemented in accordance with Fig. 2 with the aim to use the data of biomarkers as important tools in environmental risk assessment.

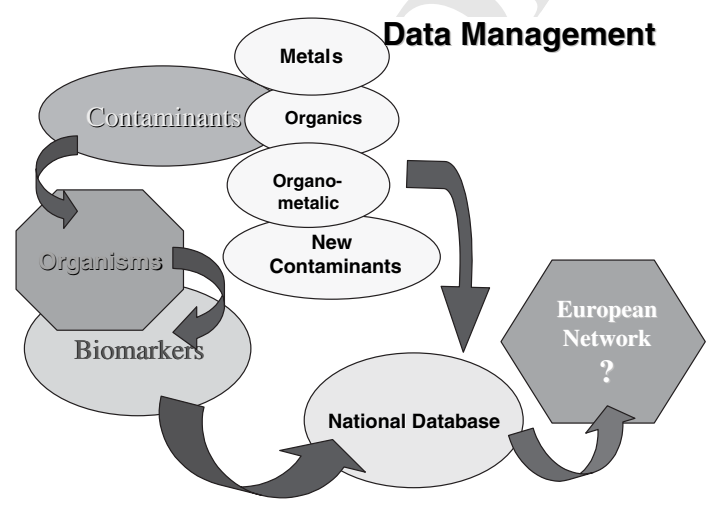

Fig. 2 Data management for the proposed monitoring program

\section{References}

Atkinson, D. E. \& G. M. Walton, 1967. Adenosine triphosphate conservation in metabolic regulation. Rat liver citrate cleavage enzyme. Journal of Biological Chemistry 242: 3239-3241.

Barroso, C. M., M. H. Moreira \& M. J. Bebianno, 2002. Imposex, female sterility and organotins in the prosobranch Nassarius reticulatus (L.) from the Portuguese Coast. Marine Environmental Progress Series 230: $127-135$.

Bebianno, M. J. \& L. M. Machado, 1997. Concentrations of metals and metallothioneins in Mytilus galloprovincialis along the South Coast of Portugal. Marine Pollution Bulletin 34: 666-671.

Bebianno, M. J. \& M. A. Serafim, 2003. Variation of metallothionein and metal concentrations in a natural clam population of Ruditapes decussatus. Archives of Environmental Contamination and Toxicology 44: 53-56.

Bebianno, M. J., A. Cravo, C. Miguel \& S. Morais, 2003. Variation of metallothionein concentrations in a field population of Patella aspera. The Science of the Total Environment 301: 151-161.

Bettin, C., J. Oehlmann \& E. Stroben, 1996. TBT-induced imposex in marine neogastropods is mediated by an increasing androgen level. Helgolander Meeresuntersuchungen 50: 299-317.

Bickham, J. W., 1990. Flow cytometry as a technique to monitor the effects of environmental genotoxins on wildlife populations. In Sandu, S. S. (ed.), In situ biological hazards of environmental pollutants. Plenum Press, New York, 94-108.

Borja, A., J. Franco, V. Valencia, J. Bald, I. Muxika, M. J. Belzunce \& O. Solaun, 2004. Implementation of the European water framework directive from the Basque country (Northern Spain): a methodological approach. Marine Pollution Bulletin 48: 209-218.

Bryan, G. W., P. Gibbs, L. G. Hummerstone \& G. R. Burt, 1986. The decline of the gastropod Nucella lapillus around the South-West England: evidence for the effect of tributyltin from antifouling paints. Journal of the Marine Biological Association of the United Kingdom 66: 611-640.

Caetano, M. \& C. Vale, 2003. Trace-elemental composition of seston and plankton along the Portuguese coast. Acta Oecologica 24: 341-349.

Cajaraville, M. P., M. J. Bebianno, J. Blasco, C. Porte, C. Sarasquete \& A. Viarengo, 2000. The use of biomarkers to assess the impact of pollution in coastal environments of the Iberian Peninsula: a practical approach. The Science of the Total Environment 247: 295-311.

Chan, J., Z. Huang, M. E. Merrifield, M. T. Salgado \& M. J. Stillman, 2002. Studies of metal binding reactions in metallothioneins by spectroscopic, molecular biology, and molecular modeling techniques. Coordination Chemistry Reviews 233-234: 319-339.

Correia, A. D., M. H. Costa, K. P. Ryan \& J. A. Nott, 2002a. Studies on biomarkers of copper exposure and
517

518

519

520

521

522

523

524

525

526

527

528

529

530

531

532

533

534

535

536

537

538

539

540

541

542

543

544

545

546

547

548

549

550

551

552

553

554

555

556

557

558

559

560

561

562

563

564

565

566

567

568

569

570

571

572

573

\begin{tabular}{|l|lll|}
\hline & Journal : HYDR & Dispatch : 23-2-2007 & Pages : 9 \\
Article No.: 0695 & $\square \mathrm{LE}$ & $\square$ TYPESET \\
MS Code : SP3525 & $\boldsymbol{C P}_{\mathrm{CP}}$ & $\square$ DISK \\
\hline
\end{tabular}


toxicity in a marine amphipod Gammarus locusta (Crustacea): II. Copper-containing granules within the midgut gland. Journal of Marine Biological Association of the United Kingdom 82: 827-834.

Correia, A. D., A. L. Pereira, M. H. Costa \& F. Carrapiço, 2002b. Functional anatomy of midgut gland of Gammarus locusta (L.) (Crustacea, Amphipoda). Journal of Marine Biological Association of the United Kingdom 82: 201-204.

Costa, F. O., T. Neuparth, M. H. Costa, C. W. Theodorakis \& L. R. Shugart, 2002. Detection of DNA strand breakage in a marine amphipod by agarose gel electrophoresis: exposure to X-rays and copper. Biomarkers 7: 451-463.

Costa, F. O., T. Neuparth, A. D. Correia \& M. H. Costa, 2005. Multi-level assessment of chronic toxicity of estuarine sediments with the amphipod Gammarus locusta: II. Individual and population endpoints. Marine Environmental Research 60: 93-110.

Dabrio, M., A. R. Rodriguez, M. Nordberg, M. J. Bebianno, G. Bordin, M. G. De Ley, I. Sestakova \& M. Vasak, 2002. Recent developments in quantification methods for metallothionein. Journal of Inorganic Biochemistry 88: 343-355.

Del Valls, T. A., M. C. Casado-Martínez, I. Riba \& J. Blasco, 2004. Linking sediment chemical and biological guidelines for characterization of dredged material. In Proccedings of the 3rd Workshop on Monitoring sediment quality at river basin scale. Understanding the behaviour and fate of pollutants. European Sediment Research Network, Apeldoorn, 101-105.

Den Besten, P. J., 1998. Concepts for the implementation of Biomarkers in environmental monitoring. Marine Environmental Research 46: 253-256.

Fernandes, S., V. Reis, F. O. Costa, M. H. Costa \& P. Sobral, 2002. Scope-for-growth of Gammarus locusta and Hediste diversicolor as a tool to evaluate sediment quality in coastal systems. Part 1. Reference energy budgets. In Duarte, P. (ed.), Proceedings of the International Conference on sustainable management of coastal Ecosystems. Ramsar, Gland.

Franco, J., A. Borja, O. Solaun \& V. Pérez, 2002. Heavy metals in molluscs from the Basque Coast (Northern Spain): results from an 11-year monitoring programme. Marine Pollution Bulletin 44: 956-976.

Gibbs, P. E. \& G. W. Bryan, 1986. Reproductive failure in populations of the dog-whelk, Nucella lapillus, caused by imposex induced by tributyltin from antifouling paints. Journal of the Marine Biological Association of the United Kingdom 66: 767-777.

Goldberg, E. D. \& K. K. Bertine, 2000. Beyond the mussel watch - new directions for monitoring marine pollution. The Science of the Total Environment 247: 165174.

Goldberg, E. D., V. T. Bowen, J. W. Farrington, G. Harvey, J. H. Martin, P. L. Parker, R. W. Riseborough, W. Robertson, E. Schneider \& E. Gambie, 1978. The mussel watch. Environmental Conservation 5: $101-125$.
Gravato, C. \& M. A. Santos, 2003. Genotoxicity biomarker' association with B(a)P biotransformation in Dicentrarchus labrax L. Ecotoxicology and Environmental Safety 55: 352-358.

Handy, R. D., A. N. Jha \& M. H. Depledge, 2002. Biomarker approaches for ecotoxicological biomonitoring at different levels of biological organisation. In Burden, F., I. McKelvie, U. Förstner \& A. Guenther (eds), Handbook of Environmental Monitoring. McGraw Hill, New York, 9.1-9.32.

Howells, G., D. Calamari, J. Gary \& P. G. Wells, 1990. An analytical approach to assessment of long term effects of low level of contaminants in the marine environment. Marine Pollution Bulletin 21: 371-375.

Husby, M. P. \& K. McBee, 1999. Nuclear DNA content variation and double-strand DNA breakage in whitefooted nice (Peromyscus leucopus) collected from abandoned strip mines, Oklahoma, USA. Environmental Toxicology and Chemistry 18: 926-931.

ICES, 1997. ICES review of the status of biological effects techniques relative to their potential application programmes. ICES Cooperative Research Report 222: 12-20.

ICES, 2001. The ICES Strategic Plan. ICES, Copenhagen.

JAMP, 1998a. JAMP guidelines for general biological effects monitoring. Joint Assessment and Monitoring Programme. Oslo and Paris Commissions, Oslo.

JAMP, 1998b. JAMP guidelines for contaminant-specific biological effects monitoring. Joint Assessment and Monitoring Programme. Oslo and Paris Commissions, Oslo.

Lagadic, L., T. Caquet \& J. C. Amiard, 1997. Intérêt d'une approche multiparamétrique pour le suivi de la qualité de l'environnement. In Lagadic, L., T. Caquet, J. C. Amiard \& F. Ramade (eds), Biomarqueurs en écotoxicologie. Aspects Fondamentaux. Masson, Paris, 393-401.

Lam, P. K. S. \& J. S. Gray, 2003. The use of biomarkers in environmental monitoring programmes. Marine Pollution Bulletin 46: 182-186.

Langston, W. J., M. J. Bebianno \& G. R. Burt, 1998. Metal handling strategies in molluscs. In Langston, J. \& M. J. Bebianno (eds), Metal metabolism in the aquatic environment. Chapman and Hall, London, 219-272.

Maria, V. L., A. C. Correia \& M. A. Santos, 2003. Genotoxic and hepatic biotransformation responses induced by the overflow of pulp mill and secondarytreated effluents on Anguilla anguilla L. Ecotoxicology and Environmental Safety 55: 126-137.

Narbonne, J. F., M. Daubèze, C. Clérandeau \& P. Garrigues, 1999. Scale of classification based on biochemical markers in mussels: application to pollution monitoring in European coast. Biomarkers 4: 415-424.

Neuparth, T., 2004. Development of methodologies to assess genotoxicity in crustaceans and fish. $\mathrm{PhD}$ thesis, Universidade Nova de Lisboa, Lisbon.

Neuparth, T., A. D. Correia, F. O. Costa, G. Lima, \& M. H. Costa, 2005. Multi-level assessment of chronic toxicity of estuarine sediments with the amphipod

\begin{tabular}{|l|lll|}
\hline & Journal : HYDR & Dispatch : 23-2-2007 & Pages : 9 \\
Article No.: $\quad 0695$ & $\square$ LE & $\square$ TYPESET \\
MS Code : $\quad$ SP3525 & $\mho_{\mathrm{CP}}$ & $\square$ DISK \\
\hline
\end{tabular}


Gammarus locusta: I. Biochemical endpoints. Marine Environmental Research 60: 69-91.

NMMP UK, 2004. The Centre for Environment Fisheries and Aquaculture Science. http://www.cefas.co.uk/ monitoring.

Nordberg, M., 1998. Metallothioneins: historical review and state of knowledge. Talanta 46: 243-254.

OSPAR, 2004. OSPAR Commission. http://www.ospar.org..

Picado, A. M., 1997. La charge énergétique adénylique: utilisation pratique pour l'évaluation des effets sublétaux des pollutions. $\mathrm{PhD}$ thesis, Ecole Pratique Hautes Etudes, Paris.

Quental, T., A. M. Ferreira \& C. Vale, 2003. The distribution of PCBs and DDTs in seston and plankton along the Portuguese coast. Acta Oecologica 24: 333-339.

Santos, M. M., N. Vieira \& A. M. Santos, 2000. Imposex in the dogwelk Nucella lapillus (L.) along the Portuguese coast. Marine Pollution Bulletin 40: 643-646.

Santos, M. M., C. C. Ten Hallers-Tjabbes, A. M. Santos \& N. Vieira, 2002. Imposex in Nucella lapillus, a bioindicator for TBT contamination: re-survey along the Portuguese coast to monitor the effectiveness of EU regulation. Journal of Sea Research 48: 217-223.

Schulte-Oehlmann, U., M. Tillmann, B. Markert, J. Oehlmann, B. Watermann \& S. Scherf, 2000. Effects of endocrine disruptors on prosobranch snails (Mollusca: Gastropoda) in the laboratory. Part II: Triphenyltin as a xeno-androgen. Ecotoxicology 9: 399-412.
Sobral, P. \& J. Widdows, 1997. Effects of copper exposure on the scope for growth of the clam Ruditapes decussatus, from Southern Portugal. Marine Pollution Bulletin 34: 992-1000.

Sobral, P. \& J. Widdows, 2000. Effects of increasing current velocity, turbidity and particle size selection on the feeding activity and scope for growth of Ruditapes decussatus from Ria Formosa, Southern Portugal. Journal of Experimental Marine Biology and Ecology 245: 111-125.

Thébault, M. T., J. P. Raffin, A. Picado, E. Mendonça, E. F Skorkowski \& Y. Le Gal, 2000. Coordinated changes of adenylate energy charge and ATP: use in ecotoxicological studies. Ecotoxicology and Environmental Safety 46: 23-28.

Theodorakis, C. W., C. D. Swartz, W. J. Rogers, J. W. Bickham, K. C. Donnelly \& S. M. Adams, 2000. Relationship between genotoxicity, mutagenicity, and fish community structure in a contaminated stream. Journal of Aquatic Ecosystem Stress and Recovery 7: 131-143.

Widdows, J. \& P. Donkin, 1992. Mussels and environmental contaminants: bioaccumulation and environmental aspects. In Gosling, E. (ed.), The Mussel Mytilus: Ecology, Physiology, Genetics and Culture. Developments in Aquaculture and Fisheries Science. Elsevier, London, 383-424.

\begin{tabular}{|l|lll|}
\hline & Journal : HYDR & Dispatch : 23-2-2007 & Pages : 9 \\
Article No.: 0695 & $\square$ LE & $\square$ TYPESET \\
MS Code : SP3525 & $\square$ CP & $\square$ DISK \\
\hline
\end{tabular}

